Int. J. Dev. Biol. 56: 653-660 (2012)

doi: $10.1387 / \mathrm{ijdb} .120018 \mathrm{sb}$

\title{
Karl Ernst von Baer (1792-1876) and Evolution
}

\author{
SABINE BRAUCKMANN* \\ Science Centre, Tartu University Library, Tartu, Estonia.
}

\begin{abstract}
The research program of Karl Ernst von Baer (1792-1876) intended to enhance the comparative approach of animal classification by demonstrating vertebrate affinities (homology). Baer visualized his ideas on development and evolution with an unpublished figure of a branching tree. To buttress his reflections on how species-specific embryogenesis produces a branching tree, he worked out a cladogram-like chart, depicting the ontogeny and phylogeny of vertebrate embryos. For Baer, changes in development were responsible for changes in phenotype. I will offer a new interpretation of Baer's ideas about evolution showing that he believed in the transformation of species and announced such views publicly.
\end{abstract}

KEY WORDS: von Baer, history of developmental biology, evo-devo, hourglass model

\section{Introduction}

As a contribution to the developing history of evo-devo, I present here a previously unknown and quite prescient view about development and evolution advanced by Karl Ernst von Baer (1792-1876) in the early 19 th century. When scrutinizing the research problems that were disregarded by neo-Darwinism (Gilbert et al., 1996; Hall, 1999; Raff, 2000; Wagner, 2000; Amundson, 2002; Arthur, 2002; Love \& Raff, 2003; Minelli \& Fusco, 2008), Entwickelungsgeschichte (developmental history) provides an important and up to now neglected topic. Baer's reflections about developmental history (Baer, 1819, 1823, 1827, 1828) offer a most appropriate point of departure, particularly since his ideas are referred to and propagated among scientists dealing with the genetic connection between evolution and development (see most recent research on phylotypic stage, hourglass model), despite debates about the validity of his research programme (Ballard, 1976; Kluge \& Strauss, 1985; Richardson \& Keuck, 2002; Poe, 2006).

Baer's law of individual development and, in particular, its third proposition (embryos of different species progressively diverge from one another during ontogeny) was newly explored when developmental biologists started to reason about the phylotypic stage and zootype, and formulated the hourglass model (Seidel, 1960; Sander, 1983, 2002; Slack et al., 1993; Duboule, 1994; Richardson etal., 1998; Galis \& Metz, 2001; Bolker, 2001; Binida-Edmonds etal, 2003; Hazkani-Covo et al., 2005; Domazet-Lošo \& Tautz, 2010; Prud'homme \& Gompel, 2010). The phylotypic stage is the period during ontogeny when general characters shared by all members of the phylum become evident; that means, embryos converge to relative similarity from very disparate beginnings, diverging again afterwards (Hall, 1997). The morphogenetic equivalent is the zootype, identifying a spatial pattern of conserved Hox gene expression, which to an extent rehabilitates Geoffroy St. Hilaire's notion of archetype (Slack et al., 1993). The overall theory was provided by the developmental hourglass model (Richardson et al., 1998; Duboule, 1994) which predicts a developmental stage of a maximum degree of similarity among the members of the phylum (Kalinka et al., 2010). In extending these morphological concepts to the molecular level, recent studies that utilized different methods of gene expression data (Domazet-Lošo \& Tautz, 2010) and phylostratigraphy (Prud'homme \& Gompel, 2010) have demonstrated how the "waist" in the hourglass arises and to which extent ontogeny and phylogeny are linked at a molecular level. All these scientists refer to Baerian comparative embryology, either regarding their results as supporting Baer's guiding principles of developmental history (Domazet-Lošo \& Tautz, 2010), or stating the basic correctness of Baer's, Darwin's and Haeckel's earlier studies (Kalinka et al., 2010).

They could have also referred to Baerian ideas to connect evolutionary and developmental processes along their time axes. However, research on Baer has placed him for some time inside the anti-Darwinian camp not paying attention to the full body of his works (Baer, 1819, 1823, 1827, 1828, 1834, 1859, 1864). Due to this oversight Baer was misplaced (so to speak), partly due to Haeckel's not entirely accurate view of Baerian scholarship and some misinterpretation of Huxley's approach towards archetypes.

Here I will present a new piece of evidence for why he is part of the history of embryology and evolutionary reasoning. Based on an unpublished hand-drawing uncovered in the Baer Collection of the University of Giessen, and some forensic analysis of a table by

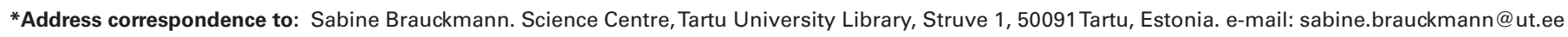

Accepted: 20 June 2012. Final, author-corrected PDF published online: 8 November 2012.

ISSN: Online 1696-3547, Print 0214-6282

(C) 2012 UBC Press

Printed in Spain 


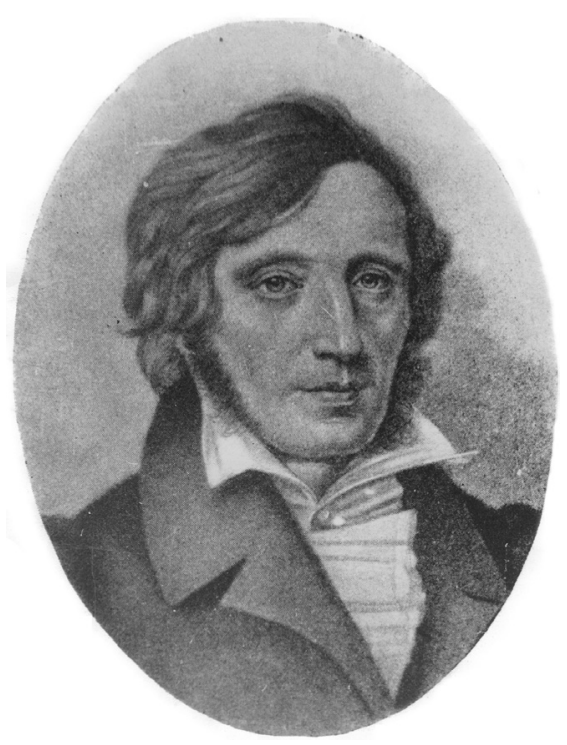

Fig. 1. Portrait of Karl Ernst von Baer (1792-1876), ca. 1834. Engraving by Friedrich Leonhard Lehmann (1787-c, 1840), after a drawing by Carl Wilhelm Hübner (1814-1879). Fond 570b, Photographic Collections, Tartu University Library, Estonia.

Baer, I argue that he did indeed have a genuine evolutionary theory, and not merely a limited view of evolution. Evidence suggesting that Baer was an evolutionist sheds new light on current debates about the role of embryology in the formation of theories of species transformation. As I show, he conceived of species transformation in the image of a "branching tree" and, much as Darwin would later do, he built his argument from evidence in comparative embryology, biogeography, paleontology, and animal breeding. In the following paragraphs I will reconstruct Baerian reflections on developmental history, relying on this tree drawing of Baer.

The present analysis also hinges on a new interpretation of Baer's use of the word "type", which should not be taken to mean an "ideal archetype", as is still commonly assumed (Mikhailov, 2012). Because of its Platonic connotations Baer intentionally did not use archetype when defining type as the "positional relationship between the organic rudiments and organs" (Baer 1828:208), which is empirically verifiable by any observer (Rieppel, 2006). The Platonic view on Baer actually goes back to an interpretation of Thomas H. Huxley's translation (Huxley, 1853; Eng, 1978; Lyons, 1995), which misconstrued Huxley's word "archetype" (Baer's Grundform) as a kind of metaphysical entity and therefore misplaced Baer's work into the anti-evolutionist category (Horder, 2006). According to Huxley, the concepts of general types and common plan (or archetypes) function as a tool for classifying animal form (Huxley, 1854, 1856: 306). To explain the transformation of major animal groups (evolution) Baer employed the concept of "(developmental) scheme". Indeed, scheme is the term he proposes to use instead of type: "Basically I could have exchanged the expressions 'type' and 'scheme' for one common term" (Baer, 1828: 257-258). ${ }^{1}$

\section{The branching tree of developmental history}

Around 1820 Baer intensified his studies of comparative embryology, applying the concept of general types, or (develop- mental) schemes to animal classification (Oppenheimer, 1953; di Gregorio, 1982; Lenoir, 1988). The general issue he addressed was "whether the developmental differences in individual animals and the structural diversity in the whole animal kingdom can be related to each other" (Baer, 1828: 202). In other words, he tackled the issue of whether there are ancestral relationships among the animal groups. Baer's point of departure was to refute the belief in the uni-directional mode of preformation, or recapitulation (Meyer, 1935; Holmes, 1947; Patterson, 1983), which he had already attacked in his dissertation (Baer, 1823), discussing mammalian fossils that were found in Prussia. In defining animal classes according to their actual structure he showed that embrogenesis of higher animals cannot include forms resembling a series of lower animals (Winsor, 1976).

By tracing the developmental stages of vertebrate and invertebrate embryos (Baer, 1819, 1828, 1834) he aimed to discover how and in what way the various organic forms emerged, whether they develop out of one another through reproduction and transformation (evolution), and how organic life came about. Using comparative embryology as his way into this question, he focused on how schemes control ontogeny and how these controlling mechanisms transform species over geological time.

In the process of working out the relationship between ontogeny and species transformation, he drew a branching tree diagram (Fig. 2A; translated into English in Fig. 2B) illustrating how he thought about the evolutionary relationship among animals, including the relationship between the invertebrate and vertebrate forms, all of which grow from the same trunk. This tree diagram makes it astonishingly clear that not only did he have an evolutionary conception of animals, but that he based his understanding of these evolutionary relationships mainly on evidence from embryology. The different branches correspond to embryological differences, with the germinal vesicle or egg being the common first stage.

Lest we conclude that by not publishing the diagram, Baer was not truly committed to an evolutionary theory, I note that the published table in Entwickelungsgeschichte der Thiere is in fact a written version of this very same branching tree diagram (Fig. 3A). If the "tree" is turned on its side, with the trunk to the left, there is a close match between this tree diagram and the published chart. In order to make this connection clear, I have redrawn the tree using the information from the chart, substituting brackets with lines, but otherwise without changing any of the content of Baer's table. In this cladogram-like drawing the close correspondence between the unpublished tree image and the published chart is evident (Fig.3B) (see also Patterson, 1983; Kluge \& Strauss, 1985).

\section{A table of developmental progress and a cladogram of species transformation}

In Baer's view, development is regulated by the same mechanism in all animals (Baer, 1834: 497-502), starting with the primary separation of the embryo into germ layers (gastrulation), followed by histological differentation (cellular specification) and the species-specific phenotype of the adult animal. In his study of Batrachian development Baer traced the mechanism of cleavage and concluded: "The norms proposed here for the divisions contain, I believe, a theory of transformations, so that if one can measure the reciprocal power of each of these rules, one is in a

\footnotetext{
1 "Im Grunde hätte ich also die Ausdrücke Typus und Schema mit einem gemeinsamen vertauschen können." (pp. 257-258) (translated by author)
} 


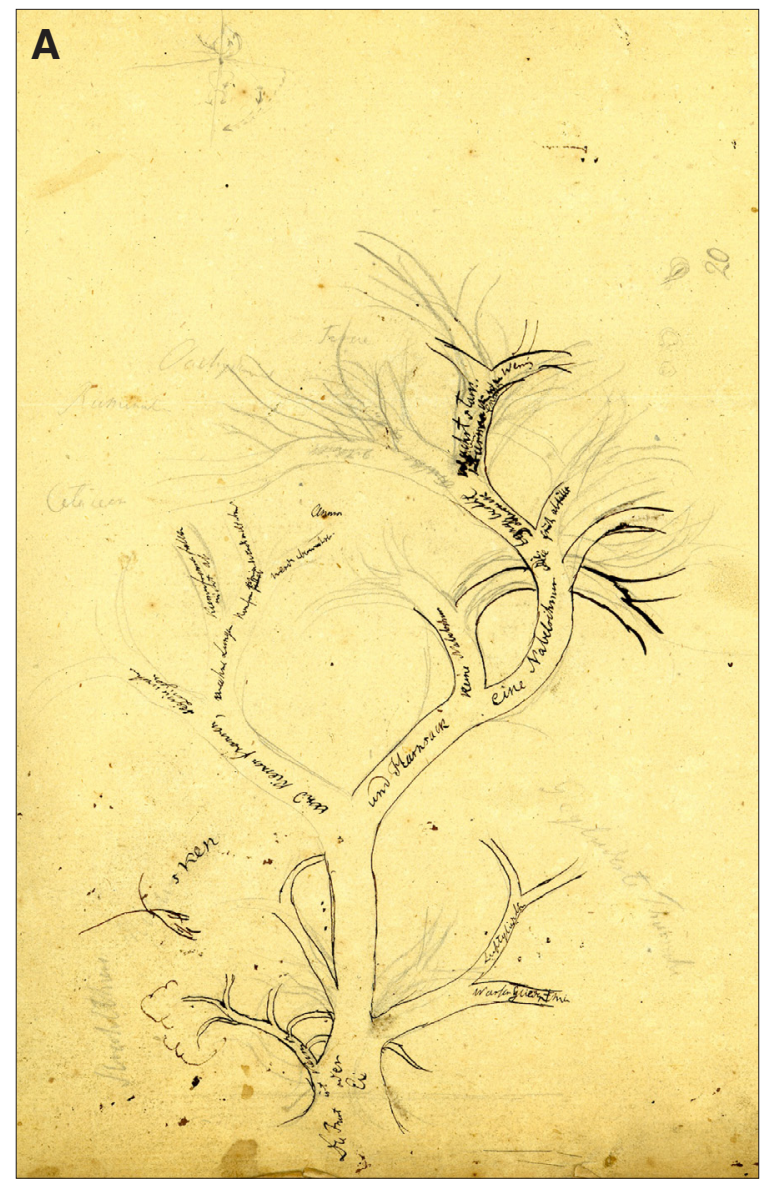

Fig. 2. Baerian tree of Developmental History. (A) Hand drawing by Karl Ernst von Baer, ca. 1826 (Giessen, Universitätsbibliothek, Special Collections, Nachlass Baer, Schriften vol. 22, Blatt/Sheet 16; reprinted with permission from Special Collections, University Library Giessen, Germany). (B) The same as (A), with an English translation of Baer's hand-writing (by author). (C) The same as (B), but rotated to the right.

position to construct the whole process a priori." (Baer, 1834: 502). When starting his studies of developmental history and animal systematics, he first utilized the (new) botanical system that classified plants on the basis of their embryonic stages, resulting in divisions between Acotyledons, Monocotyledons, and Dicotyledons (Baer, 1828: 225, 242-243; de Candolle, 1813; Farber, 1976). An advantage of using embryonic stages was that the species-specific schemes of development were more visible than in adult organisms. In the next step he inferred that the individual development of a specific animal form is determined by two relations, (1) by the formation of the animal body triggered by progressive histological (cellular) and morphological differentiation (Baer, 1828: 153-159), and simultaneously (2) by transformation of a more general form to a more specific one (Baer, 1828: 231). That means, the developmental scheme, residing inside the embryo (later he located it inside the nucleus, Baer, 1847) results in a specific segregation that, conversely, results in a specific phenotype. Baer argued that all developmental schemes procede from an initially hollow sphere (Bläschenform, or blastula) and include a vesicular form, wherein differences appear between internal and external layers, and that
Pachyderms Fishes

Ruminants

Cetaceans
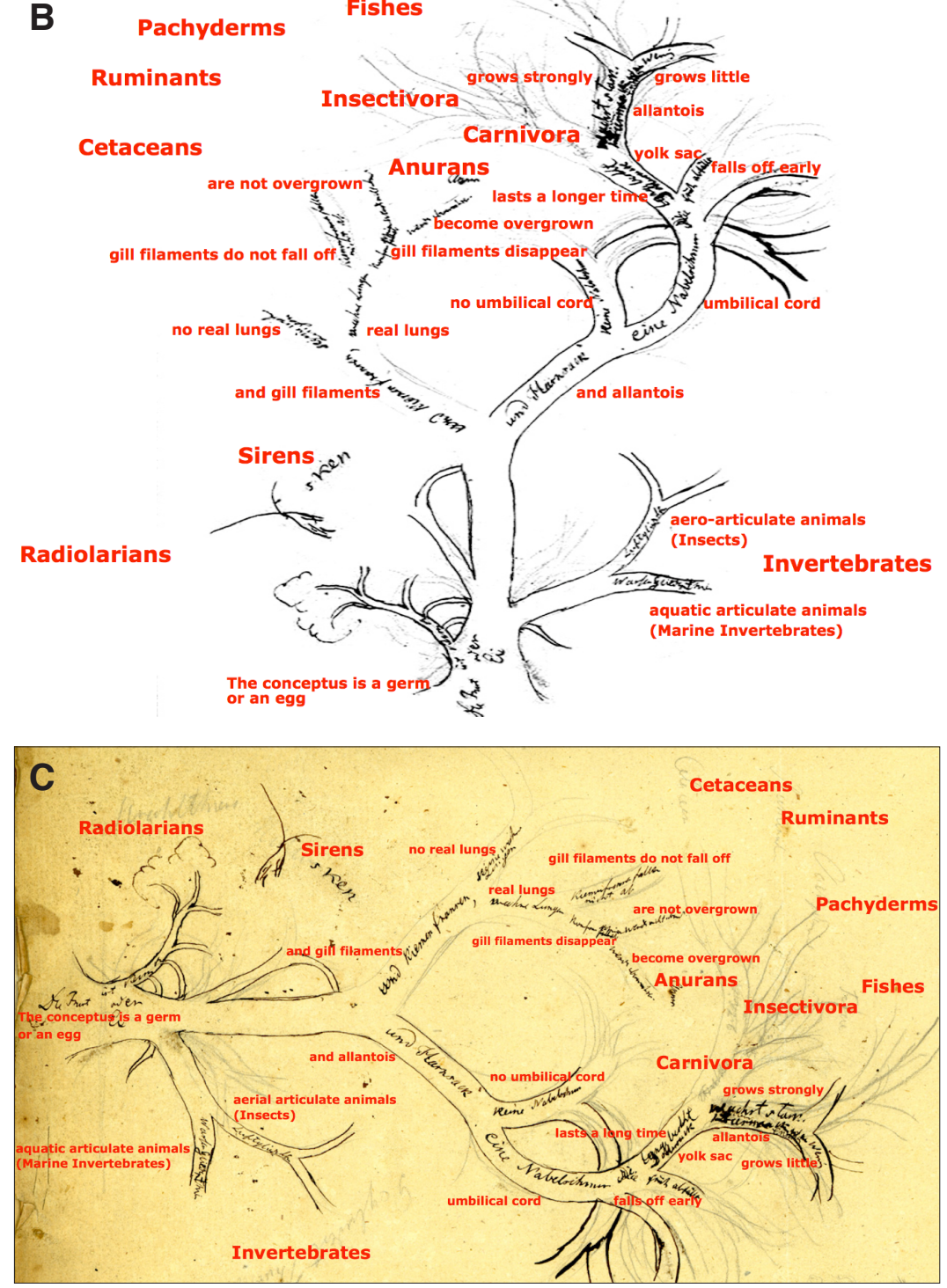

the specific form is determined by the growth and differentiation of the germ layers (Baer, 1828).

In the tree drawing the roots start from the ovum, a primordial form that is common to all animals. Then it branches, or differentiates into species-specific organs, using the classificatory value of components such as the gills, lungs, or placenta. In tracing the developmental trajectories of moving germ layers changing into organs (Bildungsbögen, see Baer 1828, table III, fig. 4; Brauckmann, 2011) he classified species according to whether branchial gills, lungs, allantois and/or umbilical cord emerges during ontogeny. Then he looked closely for what particular shapes the organs are transformed into, how long they persist, or how fast they develop. For example, at the beginning, the vertebrate developmental scheme produces nothing else than a vertebrate with a chorda dorsalis (notochord), ventral (gut) and dorsal (neural) tube, gill slits, gills and heart. Then the embryo differentiates; in some embryos gill filaments grow out, but no allantois; in others, the gills merge and an allantois develops. Animals with an outgrowing allantois form either an umbilical cord (mammals), or do not possess an umbilical cord (birds, reptiles). The umbilical cord of mammals 
A

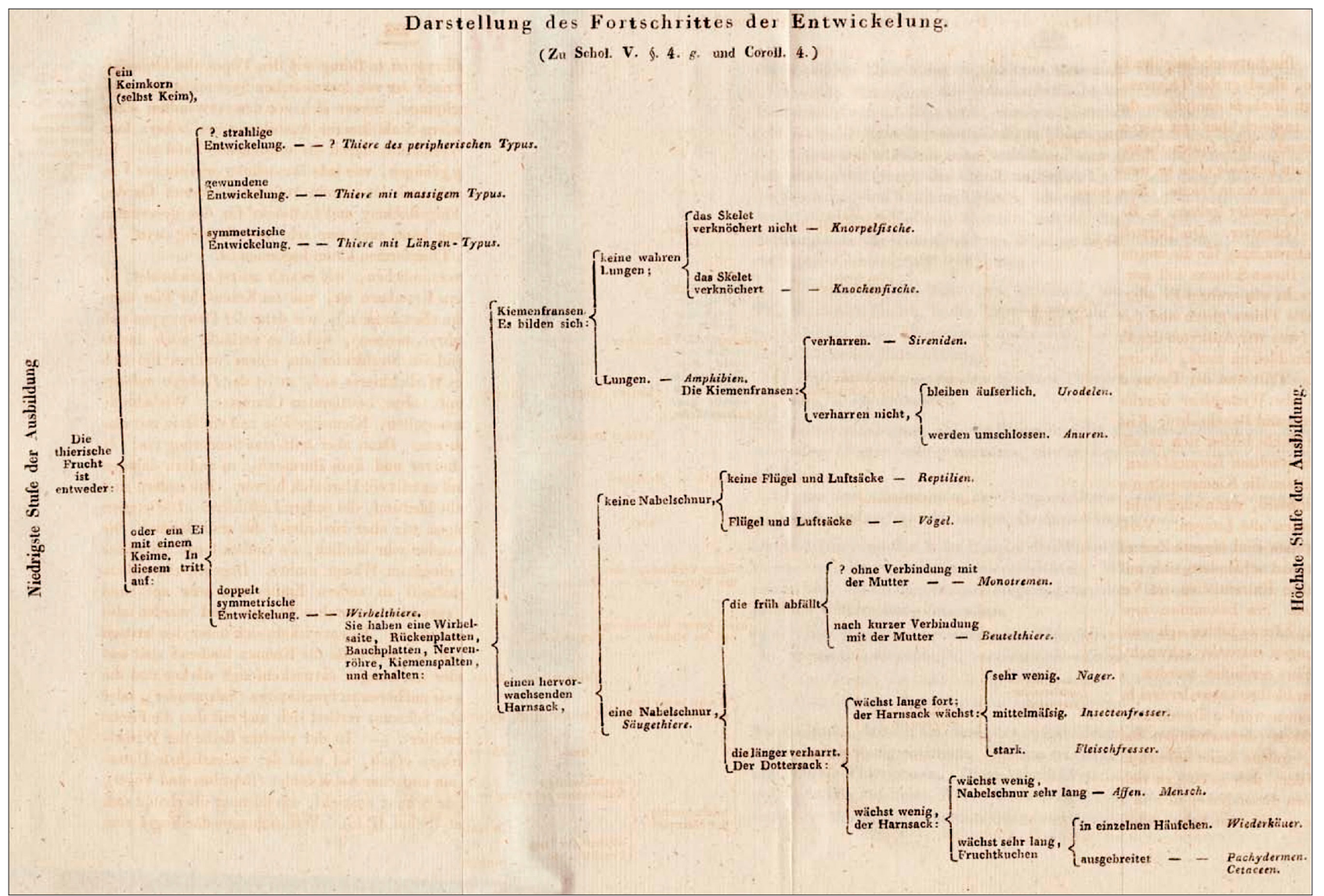

B

Highest Level of Development

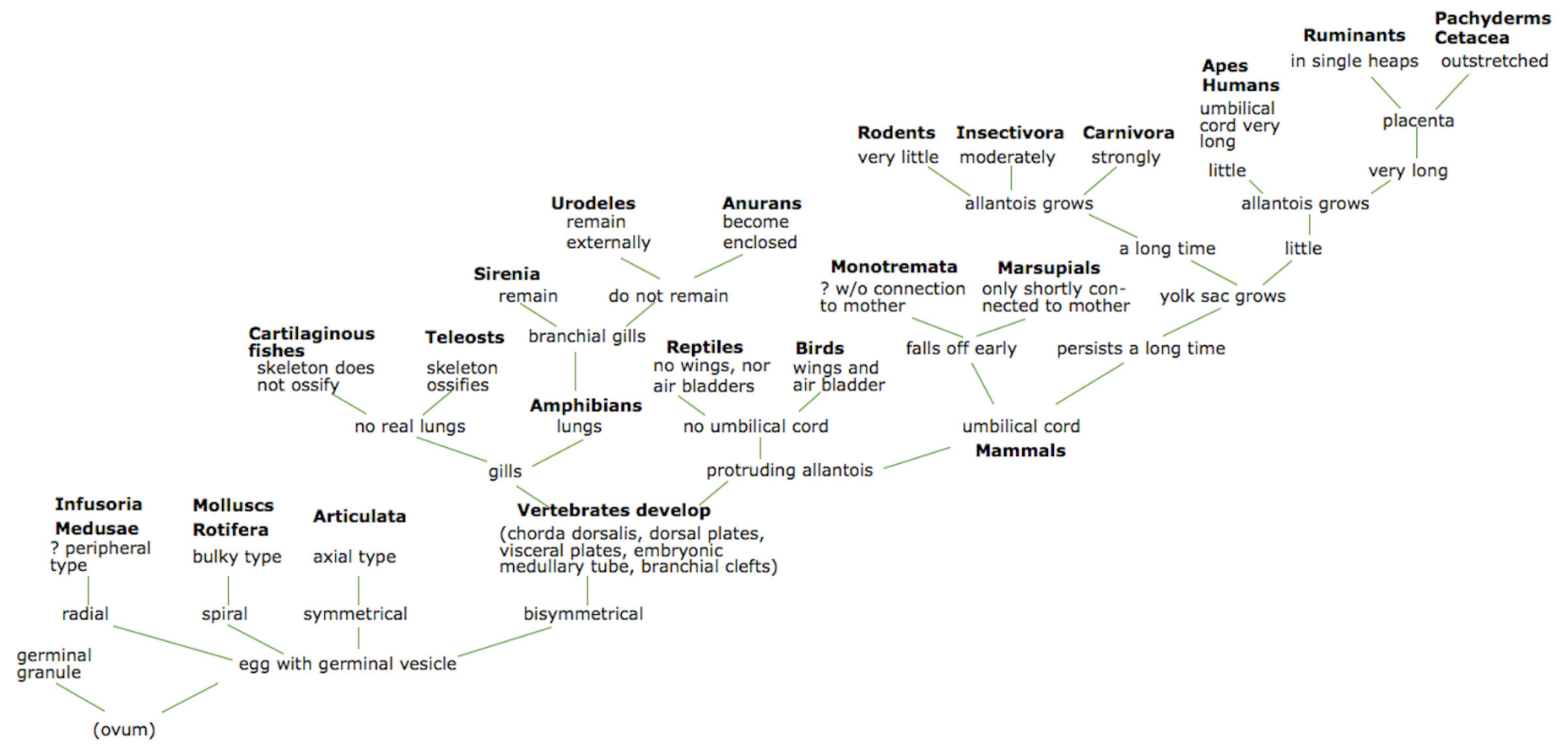

\section{Lowest Level of Development}

Fig. 3. Scheme of the progress of development in vertebrates. (A) From Karl Ernst von Baer 1828. Entwickelungsgeschichte der Thiere, vol. I, p. 225. (B) The same information as in (A), but without the brackets and an English translation of Baer's words (by author). 
either falls off early (marsupials), nourishes the embryo a long time (placental mammals), and/or forms a yolk sac. Despite that, in these species the umbilical cord can be either a short stalk or a long cord. The most fundamental difference in vertebrates that do not acquire external gills is that a simple navel forms in some animals (reptiles, birds), and that in others (apes, humans) the umbilical cord moves out (Baer 1828). The hand-drawing discontinues at this stage whereas the table continues in considering, for example, the longitudinal growth of the allantois, and in placing humans and apes beneath pigs, cows and hoofed animals, due to the complex patterns of their placenta. Baerian reflection flouted conventional Cuverian wisdom when positioning cows and pigs at the top of the tree, elevating both due their stomach perfection in comparison to apes and humans (Elwick, 2007).

Baer himself was not entirely satisfied with his table as a way to depict evolution as it attempts to model processes that happen in the 4-dimensions of space and time onto the 2-dimensional flatness of paper. He openly conceded that there does not exist any 2-dimensional depiction that sufficiently represents organic relationships, whether ontogenetic or phylogenetic.

\section{Species and evolution}

In a public lecture delivered in 1834, Baer concluded that species are as transitory as individuals: "We may also conclude [.] that the complete extinction of very many types is certain and that the emergence - not simultaneous but gradual - of many types is equally certain. [.] scientific observation, in its first infantile view, also believes that organic bodies have some constant quality, but soon recognizes that individuals are only transitory and only live on through reproduction. If science seeks the aid of history of all ages, it will recognize that species or procreative series are also transitory"(Baer, 1864:60-61). ${ }^{2}$ When species are not permanent, the question Baer asked himself was whether the different forms we recognize as varieties have developed from one another through a process of gradual transformation, but appear to be different to us because we, as ephemeral animals, cannot comprehend the scope of their developmental modifications. He elaborated on this question by citing selective cases from animal breeding, biogeography and paleontology. For instance, he noted that the guinea pig was introduced to Europe from South America in the 16th century and over merely three centuries the species changed its color, reproductive cycle and the bones of its skull. Baer agreed that there was evolution (or transformation), although he is not willing yet to admit that all animals have developed by evolving from one another. He repeated this statement in another lecture about the issue 'where do we come from', read at the Russian Academy of Sciences in St. Petersburg in March 1859 (Baer, 1859). A month later he gave a printed version to Thomas $\mathrm{H}$. Huxley and Richard
Owen whom he visited in London.

In the posthumously published treatise "On Darwin's Doctrine" (Baer, 1876) Baer reviewed at length Darwin's theory of evolution, elaborated his objections by citing examples from paleontology, animal and plant geography, and breeding experiments, and finally concluded the discussion of all the points in which he agreed with Darwin as follows: "We have just expressed that a full proof of a general transmutation is not yet given, but we must declare that a gradual occurrence of higher animal forms [.] cannot be thought of in another fashion than by transmutation, [.] we are convinced to find a defence against many objections that were raised towards Darwinism and transmutation, by the steady acceptance of an evolution in the progress of organic life. [.] To deny a transmutation natural science is not entitled to; for, to a lesser degree we still see its existence." (Baer 1876: 463, 473). ${ }^{3}$

The notion that evolution occurs through changes in development was a view of evolution that preceded Darwin (Bowler 1975, Ragan 2009) and has been reinvigorated (with genetic mechanisms) by

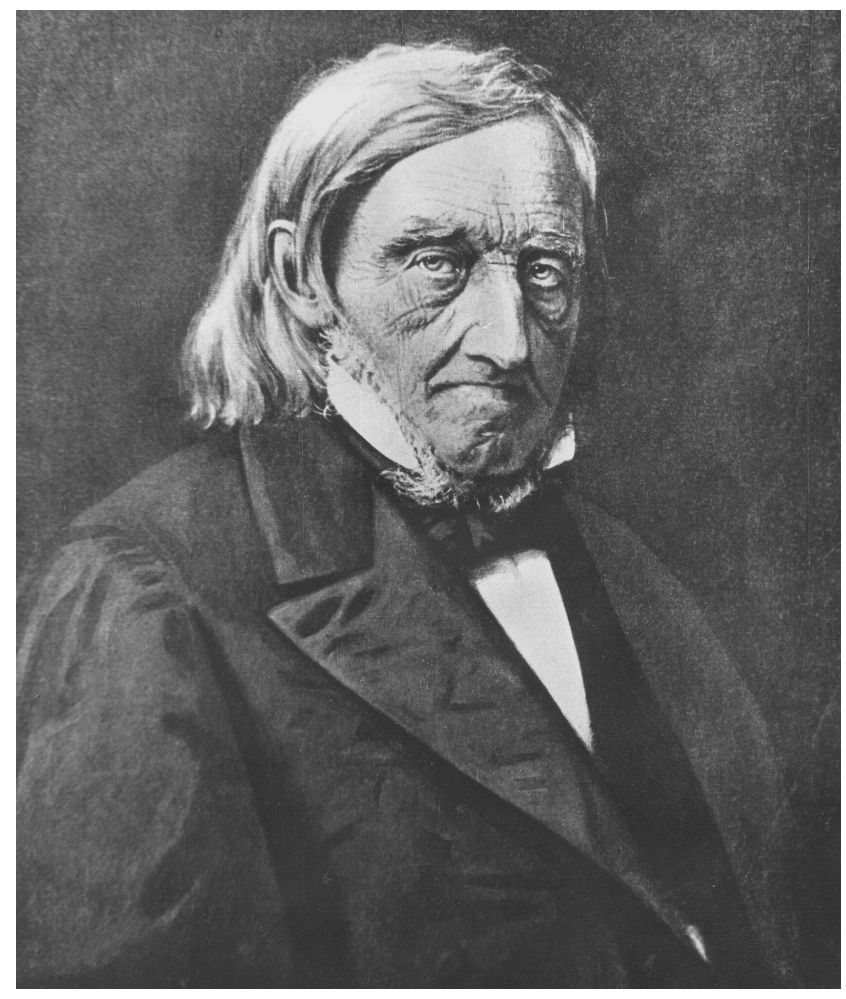

Fig. 4. Photo of the portrait of Karl Ernst von Baer (1792-1876), ca. 1873. Drawing by JulieWilhelmine Hagen-Schwartz (1824-1902). Until 1899 the original drawing belonged to the Albertus University of Königsberg in Prussia. Fond 3408-3c. Photographic Collections, Tartu University Library.

\footnotetext{
2 "Wir müssen hieraus schließen, [..] daß der völlige Untergang sehr vieler Typen gewiß und das nicht gleichzeitige, sondern allmählige Auftreten derselben ebenso gewiß ist. [..] so glaubt auch die wissenschaftliche Beobachtung bei der ersten kindischen Ansicht, die organischen Körper hätten etwas Bleibendes, sieht dann bald, daß die Individuen vorübergehend sind und nur durch die Zeugung fortleben; wenn sie die Geschichte aller Zeiten zu Hülfe nimmt, erkennt sie, daß auch die Arten oder Zeugungsreihen vorübergehend sind." (translated by author)

3 “Wir haben soeben geäußert, daß ein voller Beweis einer allgemeinen Transmutation noch lange nicht gegeben ist, aber wir müssen erklären, daß ein allmäliges Auftreten der höheren Thierformen [..] gar nicht anders gedacht werden kann, als durch Transformation [..] allein wir glauben in der festen Anerkennung einer Entwickelung im Fortgange des organischen Lebens eine Abwehr vieler Einwürfe, die man dem Darwinismus und der Transmutation überhaupt gemacht hat, zu finden. [..] Eine Transmutation überhaupt zu leugnen scheint mir die Naturwissenschaft nicht berechtigt; in geringerem Maße sehen wir sie noch jetzt bestehen." (translated by author)
} 
evolutionary developmental biology (Gilbert et al., 1996; Müller, 2001; Wagner, 2001). To claim that Baer was against evolution is to hold to a limited and, I should like to submit, a scientifically outmoded view of evolution. Rather, Baer thought that changes in developmental history were responsible for changes in the phenotype. He even drew a diagram of the branches that such developmental trajectories would have taken to produce several of the vertebrate classes. In his discussion of Darwin's evolutionary theory Baer stated that he did not doubt evolution, although he avoids the word "evolution" in his works. Further, he questioned the lack of empirical evidence for the theory of natural selection and did not believe that recapitulation was sufficient to account for evolutionary change (Baer, 1876).

This does not make him an anti-evolutionist, but shows that Baer did demand for firmer grounding in biological evidence from the evolutionary biologists of his times. Moreover, he was not the only scientist of his times who questioned the experimental record of natural selection. In the 19th century natural selection was not yet consistent with any theory of heredity (Gayon, 1998; Amundson, 2005). For example, even for Huxley (Huxley, 1860) natural selection played no role whatsoever in producing change (Schwartz, 2005). The main problem of the pros and cons of natural selection was sparked off by a fateful blend of historical narrative and addiction to one's own preconception (that means believing that 19th century embryologists believed in the typological dogma as formulated by the New Synthesis in the 20th century).

\section{Coda}

The recent spate of scholarship on the German biologist Ernst Haeckel, known for enunciating the biogenetic law (Richardson \& Keuck, 2002; Richards, 2008; Gliboff, 2009) and the gastraea theory (Brauckmann \& Gilbert, 2004) has revived discussion of earlier biologists who influenced Haeckel, such as the embryologist Karl Ernst von Baer (Raikov, 1968; Gould, 1977; Brauckmann, 2008). Baer has received attention because Haeckel synthesized Darwin's theory with Baer's developmental history in order to create his modern theory of recapitulation. Baer himself had strongly opposed earlier recapitulation ideas such as preformation (Baer, 1819, 1823, 1827; Richards, 1992) arguing that the embryo did not recapitulate lower stages of development in a hypothesized "scale of being", but instead developed from a more general to a more specific form. Because he rejected preformation, Baer is seen either as opposed to transmutation theories or at best as having a limited concept of evolution, allowing only for minor changes within the general animal "type" (Farber, 1976; Richards, 1992). However, viewing Baer through the lens of Haeckel has left us with a distorted view of Baer's views about species transformation.

The critical question how it happened that Baer was accused of ideas and opinions he did not state is a crucial issue of the history of biology in general, and in particular how we (mis)use historical facts. In an essay review Wagner (2007) raises the matter of historical fact (or interpretation of scientific concepts and analyses of experimental data) when pointing our attention to the "Synthesis historiography" of Mayr as recalled by Amundson (Mayr, 1981; Winsor, 2006) which he wryly interprets as the "victory tale of the white knight of population thinking over the anti-evolutionary dragon of typology". A most critical part of this historiography is the question of essentialism in 19th century taxonomy as presented by Mayr and others for getting accepted their interpretation of historical fact (see Winsor (2006) for a detailed critique of the metahistory). At issue here is less the historical fact than the scholarly objectivity that was renounced for a historiography of one's own preferences. Questioning the worth of such a history, Wagner, with good reason, requests for "intellectual consumer protection" to keep the scientist safe against partial and personal historians'history (Wagner, 2007: 152). However, historical knowledge offers more to the scientist (and the historian) than gaining a better perspective on present conflicts and controversies. Sometimes, old and seemingly outdated concepts and theories still affect science nowadays, direct and regulate scientific knowledge, or (the worst case scenario) might result in unwanted conceptual confusion and misinterpretation. In his comparative study of induction and positional information, Horder makes a good point (Horder, 2001). His focus is on the question on how we make judgements and choices for a specific procedure or trail to follow when doing science. He answers with "learning from past history" for procuring "guiding principles regarding the likelihood of achieving the intended outcomes through today's scientific efforts" (Horder, 2001: 124).

If past history is recorded in an accurate, unbiased and objective way it will work. Moreover, it will help to demonstrate the significance of seemingly outdated concepts, research programmes and data to most recent work of developmental evolutionary biology. However, if not, we are engrossed by distorted views resulting too often either in hagiographic accounts of scientists' history, or in sentencing scientists of the past for rather awkward "grand theories" without having formulated any. Baerian developmental history is a striking example here. The only remedy that will prevent the conversion of such metahistory into canonical wisdom shaping and influencing scientists and historians in their work is to read the original publications and to stop referring to them with eyes and minds closed.

\section{Acknowledgments}

To Ron Amundson, Alan Love, Jane Maienschein, Lynn Nyhart, Bob Richards, Marsha Richmond and Jeff Schwartz I owe a special thanks for their willingness to embark on "Debating Entwickelungsgeschichte" in Salt Lake City in 2011. The work on Baer greatly benefited from numerous discussions with Sharon Kingsland, Jessica Bolker, Richard M. Burian, Scott Gilbert and John Opitz, and the hospitality of the Department of the History of Science and Technology of Johns Hopkins University in 2010. A special thanks goes to Sulo Lembinen and Kristina Pai of Tartu University Library. The thoughtful suggestions and comments of the reviewers were helpful to improve the manuscript. Needless to say, all opinions are mine.

The work was financially supported by a Basic Research Grant MPIRT of the Estonian Ministery of Education and Research and the University of Tartu (Estonia), and Grant Br75 of the Gerda Henkel Stiftung (Germany).

\section{References}

AMUNDSON, R. (2002). Phylogenetic reconstruction then and now. Biol. Phil. 17: 679-694.

AMUNDSON, R. (2005). The Changing Role of the Embryo in Evolutionary Thought, Cambridge University Press, Cambridge.

ARTHUR, W. (2002). The emerging conceptual framework of evolutionary developmental biology. Nature 415: 757-764.

BAER, K. E. v. (1819). Über künstliche und natürliche Classification der Lebewesen und der Entwicklung. Teil I. Der Unterschied von künstlicher und natürlicher Classification bei den Naturkörpern. Teil II. Wie stellt man ein natürliches zoologisches System auf? (Unpublished Manuscript). Archive of the Academy of Sciences in St. Petersburg 
BAER, K. E. v. (1822). Vorlesung über die Zeugung, gehalten in der Deutschen Gesellschaft zu Königsberg in 1822/1823 (Ms.). Tartu University Library. Fond 61. Baer, Karl Ernst von. Mscr. 950. P-T. No. 9.

BAER, K. E. v. (1823). De fossilibus mammalium reliquiis in Prussia. Repertis dissertatio, Hartungianis, Regiomonti.

BAER, K. E. v. (1827). Die Verwandtschaftsverhältnisse unter den niederen Thierformen. Verhandlungen der Kaiserlichen Leopoldinischen-Carolinischen Akademie der Naturforscher 2: 525-762.

BAER, K. E. V. (1828). Entwickelungsgeschichte der Thiere. Beobachtung und Reflexion, Erster Theil, Bornträger, Königsberg.

BAER, K. E. v. (1834). Die Metarmorphose des Eies der Batrachier vor der Erscheinung des Embryo und Folgerungen aus inr für die Theorie der Erzeugung. Arch. Anat. Physiol. wiss. Med. 1: 481-509.

BAER, K. E. V. (1847). Auszug aus einem Bericht des Acad[emiker] v. Baer aus Triest. Bull. phys-math. Acad. Imp. de Sciences (St.-Pétersbourg) 5: col. 231-240.

BAER, K. E. V. (1859). Über Papuas and Alfuren. Ein Commentar zu den beiden ersten Abschnitten der Abhandlung "Crania selecta ex thesauris anthropologicis Academiae Imperialis Petropolitanae", Mém. Acad. Imp. de Sciences (St.Pétersbourg) 8: 260-346.

BAER, K. E. v. (1864). Das allgemeinste Gesetz in aller Entwicklung (1834). In Reden gehalten in wissenschaftlichen Versammlungen und kleinereAufsätze vermischten Inhalts, Erster Theil (Reden), H. Schmitzdorf, St. Petersburg, pp. 35-74.

BAER, K. E. v. (1886). Über Darwins Lehre. In Studien aus dem Gebiete der Naturwissenschaften. Reden gehalten in wissenschaftlichen Versammlungen und kleinere Aufsätze vermischten Inhalts. Zweiter Theil (Studien aus dem Gebiete der Naturwissenschaften), 2. Ausgabe, Vieweg, Braunschweig, pp. 235-480

BALLARD, W. W. (1976). Problems of gastrulation: Real and verbal. BioScience 26: 36-39.

BINIDA-EDMONDS, O. R. P., JEFFERY, J. E., RICHARDSON, M. K. (2003). Inverting the hourglass: quantitative evidence against the phylotypic stage in vertebrate development. Proc. Roy. Soc. (London) B 270: 341-346.

BOLKER, J.A. (2001). Evolutionary developmental biology: Developmental and genetic mechanisms of evolutionary change. In Encyclopedia of the Life Sciences, John Wiley \& Sons, www.els.net [doi: 10.1038/npg.els.0001517]

BOWLER, P. J. (1975). The changing meaning of ‘Evolution'. J. Hist. Ideas 36: 95-114.

BRAUCKMANN, S., GILBERT, S. F. (2004). Sucking in the gut: A brief history of early studies on gastrulation. In Gastrulation. From Cells to Embryo (Ed. C. D. Stern), Cold Spring Harbor Laboratory Press, Cold Spring Harbor, pp. 1-20.

BRAUCKMANN, S. (2008). The many spaces of Karl Ernst von Baer. Biological Theory 3: 85-89.

BRAUCKMANN, S. (2011). Axes, planes and tubes, or the geometry of embryogenesis. Stud. Hist. Phil. Sci. Biol. Biomed. Sci. 42: 381-390.

DE CANDOLLE, A. P. (1813). Théorie élémentairè de la botanique ou exposition des principes de la classification naturelle et de l'art de décrire et d'etudier les végétaux, Déterville, Paris.

DI GREGORIO, M. A. (1982). The Dinosaur connection: a reinterpretation of T. H. Huxley's evolutionary view. J. Hist. Biol. 15: 397-418.

DOMAZET-LOŠO, T., TAUTZ, D. (2010). A phylogenetically based transcriptome age index mirrors ontogenetic divergence patterns. Nature 468: 815-819.

DUBOULE, D. (1994). Temporal colinearity and the phylotypic progression: a basis for the stability of a vertebrate Bauplan and the evolution of morphologies through heterochrony. Development Suppl.: 135-142.

ELWICK, J. (2007). Styles of Reasoning in the British Life Scienes: Shared Assumptions, 1820-1858, Pickering \& Chatto, London.

ENG, E. (1978). Thomas Henry Huxley's understanding of evolution. Hist. Sci. 16: 291-303.

FARBER, P. L. (1976). The type-concept in zoology during the first half of the nineteenth century. J. Hist. Biol. 9: 93-119.

GALIS, F., METZ, J. A. (2001). Testing the vulnerability of the phylotypic stage: On modularity and evolutionary conservation. J. Exp. Zool. (now Mol. Dev. Evol.) 291: 195-204

GAYON, J. (1998). Darwinism's Struggle for Survival: Heredity and the Hypothesis of Natural Selection. Cambridge University Press, Cambridge

GILBERT, S. F, OPITZ, J. M., RAFF, R. A. (1996). Resynthetizing evolutionary and developmental biology. Dev. Biol. 173: 357-372.

GLIBOFF, S. H. (2009). G. Bronn, Ernst Haeckel, and the Origins of German Darwinism, MIT Press, Cambridge.

GOULD, S. J. (1977). Ontogeny and Phylogeny, The Belknap Press, Cambridge.

HALL, B. K. (1997). Phylotypic stage or phantom: is there a highly conserved embryonic stage in vertebrates? Trends Ecol. Evol. 12: 461-463.

HALL, B. K. (1998). Evolutionary Developmental Biology, 2nd. ed., Kluwer, Dordrecht.

HAZKANI-COVO, E., WOOL, D., GRAUR, D. (2005). In search of the vertebrate phylotypic stage: A molecular examination of the developmental hourglass model and von Baer's third law. J Exp Zool (Mol Dev Evol) 304B: 150-158.

HOLMES, S. J. (1947). K. E. von Baer's perplexities over evolution. Isis 37: 7-14.

HORDER, T. J. (2001). The organizer concept and modern embryology: AngloAmerican perspectives. Int. J. Dev. Biol. 45: 97-132.

HORDER, T. J. (2006). Gavin Rylands de Beer: how embryology foreshadowed the dilemmas of the genome. Nature Rev. Genet. 7: 892-898.

HUXLEY, T. H. (1853). Fragments relating to Philosophical Zoology. Selected from the Works of K. E. von Baer. In Scientific Memoirs, Selected from the Transactions of Foreign Academies of Science, and from Foreign Journals (Eds. A. Henfrey, T. H. Huxley), Taylor \& Francis, London, pp. 176-238.

HUXLEY, T. H. (1854). On the common plan of animal forms. Proc. Roy. Inst. Scientific Memoirs I: 281-283.

HUXLEY, T. H. (1856). On natural history, as knowledge, discipline and power. Proc. Roy. Inst. 2: 187-195; reprinted in (1898). Scientific Memoirs of Thomas Henry Huxley, vol. 1 (Eds. M. Forster and E. Ray Lancaster), Macmillan, London, pp. 305-314.

HUXLEY, T. H. (1860). Review of the Origins of Species. The Westminster Review 17: $541-570$

KALINKA, A. T, VARGA, K. M, GERRARD, D. T, PREIBISCH S., CORCORAN, D. L., JARRELS, J., OHLERS, U., BERGMAN, C. M., TOMANCAK, P. (2010) Gene expression divergence recapitulates the developmental hourglass model. Nature 468: 811-816.

KLUGE, A. G, STRAUSS, R. E. (1985). Ontogeny and systematics. Ann. Rev. Ecol. Syst.16: 247-268.

LENOIR, T. (1988). Kant, von Baer, and causal-historical thinking in biology. Poetics Today 9: 103-115.

LOVE, A. C., RAFF, R. A. (2003). Knowing your ancestors: Themes in the history of evo-devo. Evo. Devo. 5: 327-330.

LYONS, S. L. (1995). The origins of T. H. Huxley's saltationism: History in Darwin's shadow. J. Hist. Biol. 28: 463-494.

MAYR, E. (1981). Biological classification: Toward a synthesis of opposing methodologies. Science 214: 510-516.

MEYER, A. W. (1935). Some historical aspects of the recapitulation idea. Quart. Rev. Biol. 10: 379-396.

MIKHAILOV, A. T. (2012). Russian comparative embryology takes form: A conceptual metamorphosis toward "evo-devo". Evo. Devo.14: 9-19.

MINELLI, A., FUSCO, G. eds. (2008). Evolving Pathways. Key Themes in Evolutionary Developmental Biology, Cambridge University Press, Cambridge.

MÜLLER, G. B. (2007). Evo-devo: Extending the evolutionary synthesis. Nature Rev. Genet. 8: 943-949.

OPPENHEIMER, J. M. (1963). Karl Ernst von Baer's beginning insights into causalanalytical relationships during development. Dev. Biol. 7: 11-21.

PATTERSON, C. (1983). How does phylogeny differ from ontogeny? In Development and Evolution. The Sixth Symposium of the British Society for Developmental Biology (Eds. B. C. Goodwin, N. Holder, C. C. Wylie), Cambridge University Press, London, pp. 1-31.

POE, S. (2006). Test of von Baer's law of the conservation of early development Evolution 60: 2239-2245.

PRUD'HOMME, B., GOMPEL, P. (2010). Evolutionary biology: Genomic hourglass Nature 468: 768-769.

RAFF, R. A. (2000). Evo-devo: the evolution of a new discipline. Nature Rev. Genet. 1: 74-79.

RAGAN, M. A. (2009). Trees and networks before and after Darwin. Biology Direct 4: 43 [http://www.biology-direct.com/content/4/1/43].

RAIKOV, B. E. (1968). Karl Ernst yon Baer, 1792-1876. Sein Leben und sein Werk 
Johann Ambrosius Barth, Leipzig

RICHARDS, R. J. (1992). The Meaning of Evolution: The Morphological Construction and Ideological Reconstruction of Darwin's Theory. The University of Chicago Press, Chicago.

RICHARDS, R. J. (2008). The Tragic Sense of Life: Ernst Haeckel and the Struggle over Evolutionary Thought. The University of Chicago Press, Chicago.

RICHARDSON, M. K, MINELLI, A, HANKEN, J. (1998). Phylotypic stage theory (Letter). Trends Ecol. Evol. 13: 516.

RICHARDSON, M. K., KEUCK, G. (2002). Haeckel's ABC of evolution and development. Biol Rev 77: 495-528.

RIEPPEL, O. (2006). 'Type' in morphology and phylogeny. J. Morphol. 267: 528-535.

SANDER, K. (1983). The evolution of patterning mechanisms: gleanings from insect embryogenesis and spermatogenesis. In Development and Evolution (Eds. B C. Goodwin, N. Holder, C. C. Wylie), Cambridge University Press, Cambridge, pp. 137-159.

SANDER, K. (2002). Ernst Haeckel's ontogenetic recapitulation: irritation and incentive from 1866 to our time. Ann. Anat. 184: 523-533.
SCHWARTZ, J. H. (2005). Darwinism versus Evo-Devo: a late-nineteenth century debate. In A Cultural History of Heredity III: 19th and Early 20th Centuries (Eds. S. Müller-Wille, H.-J. Rheinberger), MPI Preprint 294, Berlin, pp. 67-84.

SEIDEL, F. (1960). Körpergrundgestalt und Keimstruktur. Eine Erörterung über die Grundlagen der vergleichenden und experimentallen Embryologie und deren Gültigkeit bei phylogenetischen Untersuchungen. Zool. Anz. 164: 245-305.

SLACK, J. M. W., HOLLAND, P. W. H., GRAHAM, F. C. (1993). The zootypic and the phylotypic stage. Nature 361: 490-492.

WAGNER, G. P. (2000). What is the promise of developmental evolution? Part I: Why is developmental biology necessary to explain evolutionary innovations?. J. Exp. Zool. (Mol. Dev. Evol.) 288: 95-98.

WAGNER, G. P. (2007). How wide and how deep is the divide between population genetics and developmental evolution? Biol. Phil. 22: 145-153.

WINSOR, M. P. (1976). Starfish, Jellyfish, and the Order of Life. Yale University Press, New Haven.

WINSOR, M. P. (2006). The creation of the essentialism story: An exercise in metahistory. Hist. Phil. Life Sci. 28: 149-174. 


\section{Further Related Reading, published previously in the Int. J. Dev. Biol.}

Evolutionary embryology resurrected in Japan with a new molecular basis: Nori Satoh and the history of ascidian studies originating in Kyoto during the 20th century

Shigeru Kuratani, Hiroshi Wada, Rie Kusakabe and Kiyokazu Agata

Int. J. Dev. Biol. (2006) 50: 451-454

August Rauber (1841-1917): from the primitive streak to Cellularmechanik

Sabine Brauckmann

Int. J. Dev. Biol. (2006) 50: 439-449

Putting evo-devo into focus. An interview with Scott F. Gilbert

Alexander T. Mikhailov

Int. J. Dev. Biol. (2005) 49: 9-16

From embryonic induction to cell lineages: revisiting old problems for modern study Tokindo S. Okada

Int. J. Dev. Biol. (2004) 48: 739-742

Evo-Devo: evolutionary developmental mechanisms

Brian K Hall

Int. J. Dev. Biol. (2003) 47: 491-495

The amphioxus genome in Evo-Devo: archetype or "cul de sac'?

J Garcia-Fernandez, DEK Ferrier, C Minguillon, C Cebrian

Int. J. Dev. Biol. (2001) 45: S137-S138

A history of mammalian embryological research

H Alexandre

Int. J. Dev. Biol. (2001) 45: 457-467

Louis Sébastien Tredern de Lézérec (1780-18?), a forgotten pioneer of chick embryology $J \mathrm{C}$ Beetschen

Int. J. Dev. Biol. (1995) 39: 299-308

Epigenesis versus preformation: first chapter of the Russian embryological research A T Mikhailov

Int. J. Dev. Biol. (1997) 41: 755-762

5 yr ISI Impact Factor $(2011)=2.959$

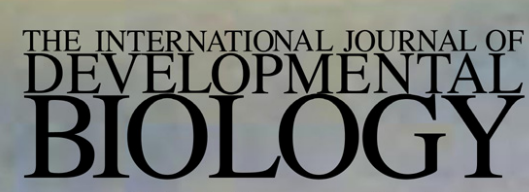

Volume 47 Nos. $7 / 8$

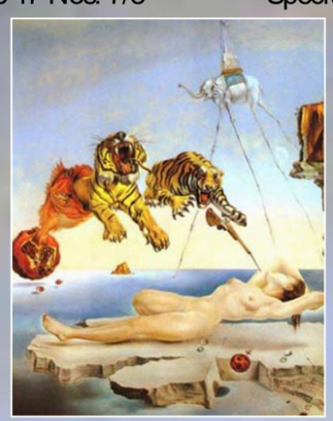

Evolution \& Development

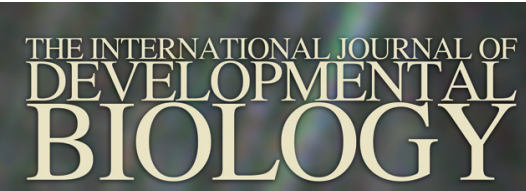

Special Issue

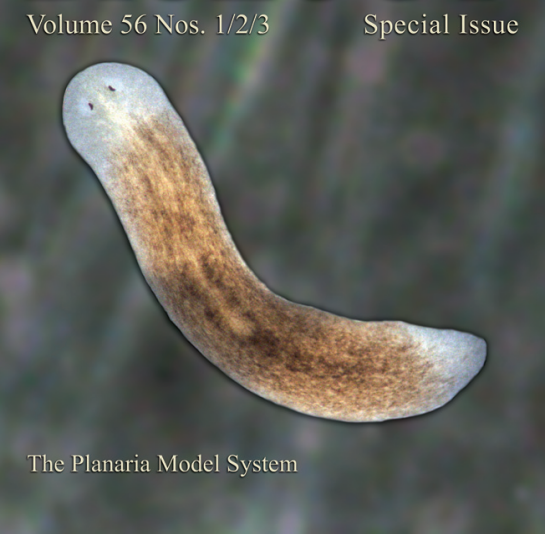

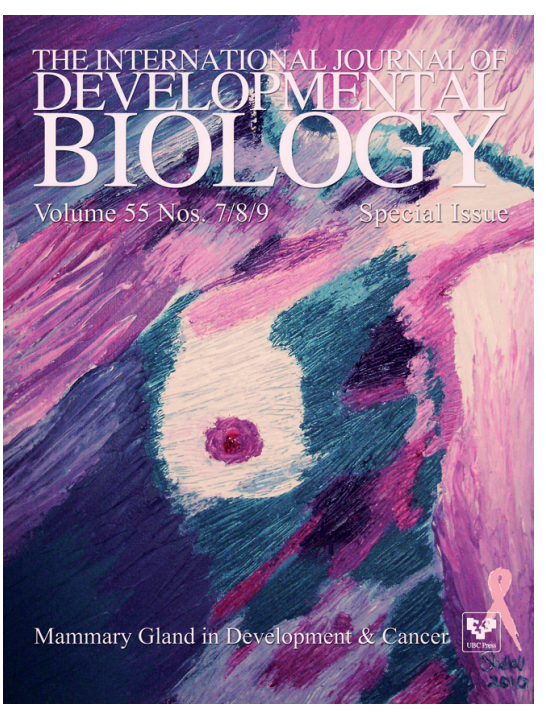
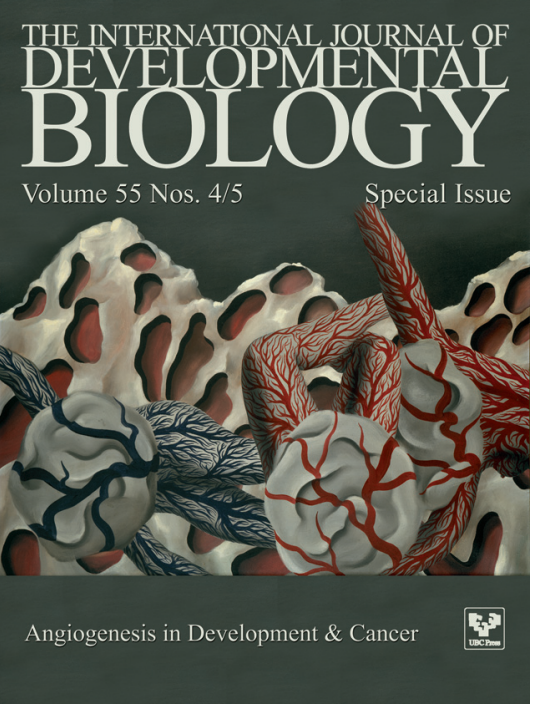